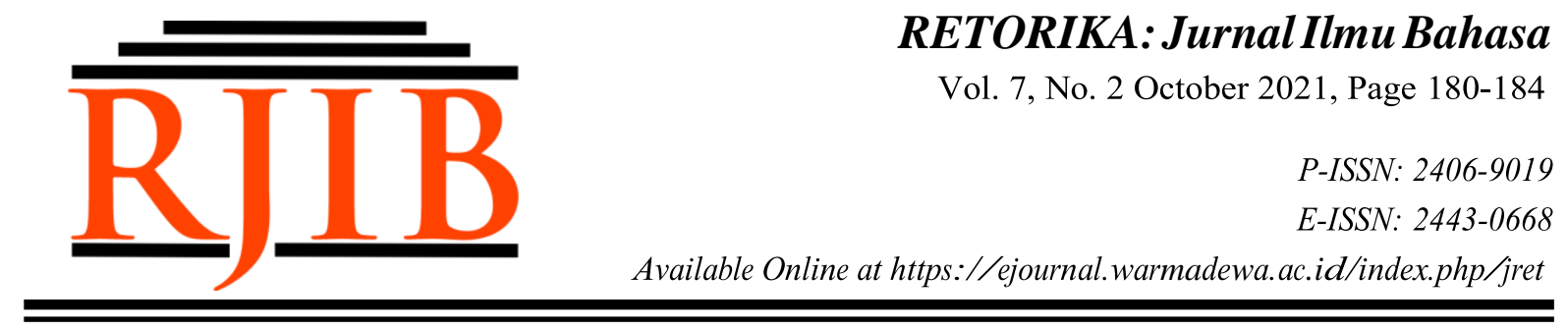

\title{
Speech Acts Variation in Social Media Instagram @punapibali
}

\author{
Putu Nindhya Nirmala*, I Nyoman Kardana and Agus Darma Yoga Pratama \\ Universitas Warmadewa, Denpasar, Bali-Indonesia \\ *nindhyanirmala@gmail.com
}

How to cite (in APA style):
Nirmala, P. N., Kardana, I. N., \& Pratama, A. D. Y. (2021). Speech Acts Variation in Social Media Instagram @ 15/10/2021
$\quad$ Retorika: Jurnal Ilmu Bahasa, 7(2), 180-184. doi: https://doi.org/10.22225/jr.7.2.3199.180-184

\begin{abstract}
This research aims to examine the speech act functions found on Instagram @ punapibali and describe the types of speech acts used by the informant and news writer. Thus, this study was conducted using the qualitative descriptive method and by using the pragmatics fundamentals proposed by Wijana (1996) and the speech act function theory of Searle (1979) as the basis for examining the speech act functions used by the informant and news writer according to its type. The data were collected through the observation method accompanied by an act of scrutinizing speeches and sentences of the informant and news writer @ punapibali. The oral data were collected from the conversations use to know the intonation and tone of the speech delivered. The data analysis results are presented descriptively. The results of data analysis showed there are 40 types of speech acts used in the caption of Instagram @ punapibali. The expressive function is manifested in the act of asking for an apology, thanking someone, and congratulating someone. The directive function includes the act of asking, suggesting, advising, and urging. The commissive function includes expressing abilities and promising. The assertive function includes notifying, affirming, and stating. The declarative function is manifested in the act of declaration.
\end{abstract}

Keywords: Types of speech act, functions of speech act, social media

\section{INTRODUCTION}

Human speech can be expressed through the media, both oral and written. Currently, Instagram social media is one application that is in great demand by the public. The language used in the Instagram comment also varies and tends to use a variety of casual language, even several sentences indicate impoliteness. One of the Instagram accounts that always uses language as a means of expressing language expressions so it is also possible for speech events to occur, namely on the Instagram @ punapibali.

According to Verhaar (1996), pragmatics is a branch of linguistics that discusses what is included in the structure of language as a means of communication between speakers and listeners, and as a reference to language signs on "extralingual" matters being discussed. In actual speech acts, five aspects of the speech situation must be considered which include the speaker and the speech partner, the context of the speech, the purpose of the speech, the speech act as an action or activity and speech as a product of the verbal act (Leech, 1993). (Budiarta \& Gaho, 2021) defined pragmatic as one of five linguistic branches (phonetics, phonology, syntax, semantics), that focuses on studying of language meaning.

Searle (1979) divides illocutionary acts into five categories, namely: (1) Assertive, namely speech that binds the speaker to the truth of the proposition expressed, for example stating, suggesting, boasting, complaining, and claiming; (2) Directive, a speech that is intended for the speech partner to act according to the 
speech, for example, ordering, ordering, begging, advising, and recommending; (3) Commissive, which is an act that requires the speaker to commit to something in the future. Examples are promising, swearing, rejecting, threatening, and guaranteeing; (4) Expressive, namely the expression of attitudes and feelings about a situation or reaction to people's attitudes and actions. Examples of congratulating, grateful, regretting, apologizing, welcoming, and grateful; (5) Declarative, which is an illocution that cause a change or conformity between a proposition and reality. Examples are baptizing, firing, naming, and punishing. Besides, other ideas comes from Wijana (1996) that speech acts can be divided into four types, namely direct speech acts, indirect speech acts, literal speech acts, and non-literal speech acts.

Related to the background above, several previous studies are used as references in this study, such as in research written by Sosiowati (2013) which analyzed the politeness of the language used by politicians that can be categorized as polite politicians because, during their communication, there are attempts to ignore the turn and attempt to dominate. Fatmayanti (2017) conducted a study that showing the speech acts that are more dominant for parents to use are directive speech act. In addition, Anwari (2017) also conducted a similar study with her research which shows that illocutionary acts in the speech of the Madurese community in Kalidandan Village, Pakuniran, Probolinggo includes atanyah "asking", (2) jek apermainagin perkabinan "don't play in marriage", (3) kasok'on "thanking", (4) nyesel "regret", (5) songkan "hesitate", (6) sabbher "patient", (7) laep "famine", and (8) ngandung kade' "married by accident".

Furthermore, the research is written by Nuramila (2019) found that the form of speech acts is in the form of writing with the intention of speech, namely to influence, invite, do something, tell/explain something, expect attention, stimulate, prohibit, praise, criticize, appreciate, and complaints. Finally, previous research related to this research was written by Sidiq (2020) figures such as Dewi Ayu, Salim, and Adinda who have the character of the protagonists. The speech asking for the character of the protagonist to be very clear and related to the context they are speaking.

Based on the relevant research above, this research is different from previous research because this study analyzes the types and functions of speech acts contained in the Instagram feed of @ punapibali. The objectives of this study are based on the following background: a) to examine the speech act functions found on Instagram @ punapibali, b) to describe the types of speech acts used by the informant and news writer.

Based on the background above, the purpose of this study is to describe the types of speech acts contained in the Instagram feed of @ punapibali and to describe the function of speech acts found in the Instagram feed of @ punapibali.

\section{METHODS}

This study makes use of a qualitative method. The oral data were collected from the conversations use to know the intonation and tone of the speech delivered. The data analysis results are presented descriptively. The results of data analysis showed there are 40 types of speech acts used in the caption of Instagram @ punapibali. The data analysis was classified by the function of speech acts. After the data had been identified, then writing sentence by sentence using a laptop. Then the data were classified according to the type of speech acts: declarative, assertive, expressive, commisive, directive. Having been classified, the categorization was done according to the functions of each speech act found. In this research, Searle's theory was used to examine the functions of speech acts and describe the types of speech acts through the theory proposed by Wijana (1996). The results of data analysis are presented descriptively, which means the data were presented using written text.

\section{RESULT AND DISCUSSION Type of Speech Acts}

Wijana (1996) states that speech acts can be divided into four types, namely direct speech acts, indirect speech acts, literal speech acts, and non-literal speech acts.

\section{Direct Speech}

Direct speech acts are declarative sentences that are functioned conventionally to say something, interrogative sentences to ask questions, and command sentences to invite, order, and beg (Wijana, 1996). As for some data 
found in the Instagram @ punapibali which states as types of direct speech act as follows.

(1) Telah terjadi kecelakaan yang melibatkan motor gede dan motor matic di Jalan Mahendradatta, Denpasar sore ini, Sabtu (26/9). Belum diketahui secara pasti terkait kronologi kecelakaan dan kondisi dari korban.

Dihimbau kepada pengendara agar selalu berhati-hati dalam berkendara. [PB - 26/09/2020]

Data (1) can be categorized into types of direct speech acts in the form of imperative sentences with the speech mode used to appeal and invite. Command sentences functioned conventionally to order, invite, and beg. As for the marker sentence that is included in the type of direct speech act, that is "Dihimbau kepada pengendara agar selalu berhati-hati dalam berkendara". In this case, the phrase "dihimbau" is included in the function of commanding in the form of an appeal to take an action. The purpose of speech (1) is that the author urges and advises the public to always be careful when driving. This is done to maintain the safety of the rider so that unwanted things do not occur.

\section{Indirect Speech}

Indirect speech acts are utterances that are expressed indirectly and are usually not answered directly, but the intentions and implications must be carried out immediately (Wijana, 1996).

(24) Bersumber dari komentar pembaca:

@batues_fanbase: "KALAU PPKM TIDAK

EFEKTIF TIDAK USAH DILANJUTKAN!! GUNANYA PPKM APA? KALAU BESOK PAGINYA ORANG RAMAI KE PASAR!! EMANGNYA VIRUS KELUAR ADA JAM NYA?? DAPAT DARIMANA PEMIKIRAN BDOH SPERTI ITU?!"

[PB - 21/01/2021]

In the data above, it can be entered in the form of directive speech acts which are conveyed indirectly by using the command to be silent, marked with the exclamation mark (!). This can be seen in the speech from the account (a) batues fanbase "KALAU PPKM TIDAK EFEKTIF TIDAK USAH DILANJUTKAN!! GUNANYA PPKM APA? KALAU BESOK
PAGINYA ORANG RAMAI KE PASAR!! EMANGNYA VIRUS KELUAR ADA JAM NYA?? DAPAT DARIMANA PEMIKIRAN $B D O H$ SPERTI ITU?!" In the quote, it can be seen that the speech "KALAU PPKM TIDAK EFEKTIF TIDAK USAH DILANJUTKAN!! " is an order for the government to reconsider the PPKM plan if it is deemed ineffective and harmful to the lower class by conveying it indirectly.

\section{Function of Speech Acts}

Searle (1979) divides illocutionary acts into five categories, namely: (1) Assertive, namely speech that binds the speaker to the truth of the proposition expressed, for example stating, suggesting, boasting, complaining, and claiming; (2) Directive, a speech that is intended for the speech partner to act according to the speech, for example, ordering, ordering, begging, advising, and recommending; (3) Commissive, which is an act that requires the speaker to commit to something in the future. Examples are promising, swearing, rejecting, threatening, and guaranteeing; (4) Expressive, namely the expression of attitudes and feelings about a situation or reaction to people's attitudes and actions. Examples of congratulating, grateful, regretting, apologizing, welcoming, and grateful; (5) Declarative, which is an illocution that causes a change or conformity between a proposition and reality. Examples are baptizing, firing, naming, and punishing.

\section{Directive Speech Act}

The data that will be presented in the analysis below will explain the data included in the speech act function of the directive "reprimand". In this case, the word "reprimand" has the meaning of an action to give a warning to someone who is considered to have committed an error or act that is not following the applicable rules.

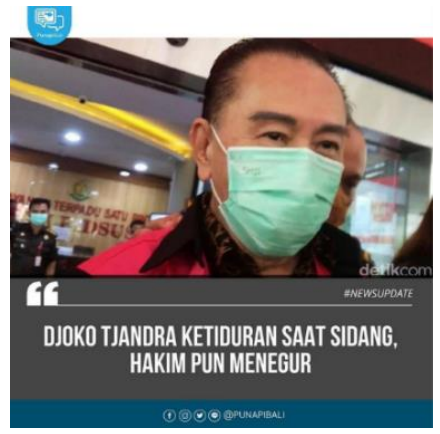


Data 51: PB (Photo) - 22/10/2020 [DI]

\section{Index Information:}

"The defendant in the case of transfer of collection rights or cessie Bank Bali, Joko Soegiarto alias Djoko Tjandra fell asleep at the court. The man who had been a fugitive for 11 years was reprimanded by the panel of judges.

Reporting from the @detikcom website page, when the trial was running, suddenly the head of the panel of judges Muhammad Sirat stopped Djoko Tjandra's attorney who was reading the exception. "I reminded the defendant not to sleep!" said Muhammad Sirat."

Speech on data (51) is a directive speech act. The sentence which indicates the word "reprimand" is the sentence "I remind the defendant not to sleep!". The data has a literal meaning that the panel of judges, Muhammad Sirat, rebuked Djoko Tjandra during the trial. The speech occurred in court when the panel of judges stopped Djoko Tjandra's attorney who was reading the exception. The data above is included in the directive reprimand speech act function because it has the form of a sentence that is following the context and characteristics of the meaning of "reprimand" itself, namely giving a warning to someone who has committed an unsavory act, giving an awareness effect on someone doing something, and the form of a warning sentence usually ends with a sign (!) at the end of the sentence which means that the warning or reprimand must be carried out immediately. Besides, when viewed from various aspects, the speech "I remind the defendant not to sleep!" has a pragmatic meaning to raise awareness of speech partners to do something according to what the speaker has warned. Through the word "I remind" means that the function of directive speech is identified in the speech because it is directly functioned to give a firm warning to the speech partner to obey what is said by the speaker not to sleep during the trial.

\section{Expressive Speech Act}

The function of expressive speech acts which will be explained is the function of expressive speech "apologizing". Apologizing is a way of showing that someone has admitted to being wrong and has learned from it. The results of data analysis which state expressive speech acts "apologize" are as follows:

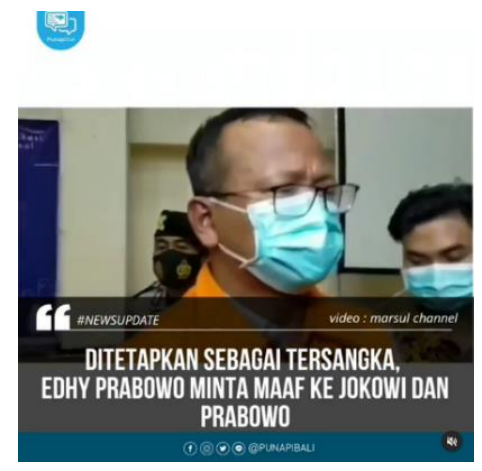

\section{Data 62: PB (Video) - 26/11/2020 [EK] Index Information:}

"First I apologize to Mr. Jokowi, I have betrayed his trust. Apologize to Mr. Prabowo Subianto, my teacher, who has taught many things," said Edhy.

Through the example (62), it is seen that Edhy Prabowo apologizes to President Joko Widodo (Jokowi) to the Minister of Defense who is also Chairman of Gerindra, Prabowo Subianto. The context of the situation in this speech was when the Minister of Marine and Fisheries, Edhi Prabowo, became a suspect in receiving bribes related to the export of lobster or fries. Based on this description, there was an expressive speech act of apologizing which was spoken by Edhy Prabowo. The phrase "apologize" in the sentence "First I apologize to the President, I have betrayed his trust. Apologies to Mr. Prabowo Subianto, my teacher, who has taught many things". The phrase "apologize" has the function of expressing regret for mistakes that have been made. If a speaker does not commit a mistake that is detrimental to the state, the speaker will not apologize. However, in this context the phrase "apologize" is conveyed by speakers as an expression of regret for disappointing the people around him who have trusted him due to corruption committed by speakers. Besides, the speaker says sorry as a form of responsibility that will be done for what has happened.

\section{CONCLUSION}

The research conducted shows that there are 40 types of speech acts were found on Instagram @ punapibali, namely: direct speech acts (18 data), indirect speech acts (6 data), 
literal speech acts (5 data), non-literal speech acts. (5 data), and literal indirect speech acts (6 data). In this study, the most dominant type of speech act that appeared was direct speech act with a frequency of appearance is 18 data. Direct speech acts are widely used in Instagram @ punapibali to ask questions, command, and provide information because the Instagram @ punapibali shows that the intensity of the presence of direct and indirect meanings appears more often than other meanings. In the Instagram feed of @ punapibali, the author tends to use the meaning of the word appeal and invitation more often. The author advises and calls on the public to be more vigilant about things such as criminal crimes or calls to adhere to government regulations. Besides, there are also other meanings such as praise, satire, and messages in the Instagram feed of @ punapibali. Furthermore, in this study, 42 speech act functions were found, including 10 assertive speech acts, 9 directive speech acts, 1 commissive speech act, 14 expressive speech acts, and 8 declarative speech acts. The type of speech act with the most dominant frequency of appearance is the function of expressive speech acts. The most prominent functions of expressive speech acts are expressed in the expression of happiness, admiration, condolences, apologies, and congratulation.

\section{REFERENCES}

Anwari. 2017. Linguistika, september 2017. Linguistika, Universitas Udayana, 24(47), 203-220.

Austin, J. 1962. Austin J. L. -How to Do Things With Words.pdf.

Budiarta, I. W., \& Gaho, R. (2021). Deixis Analysis on Zootopia Movie Script: A Pragmatic Study. IJOTL-TL, 6(3), 261-274.

Fatmayanti, U. 2017. Tindak Tutur Orangtua dalam Pembentukkan Karakter Anak. Universitas Islam Negeri Maulana Malik Ibrahim, 4, 9-15.

Nuramila. 2017. Tindak Tutur Bahasa Indonesia Dalam Unggahan Media Sosial Instagram @Liputan6 (Kajian Pragmatik). Universitas Negeri Makasar, 6(c).

Searle, J. R. 1979. Studies in the theory of speech acts. In Cambridge University Press.

Sidiq, M., \& Abdul, N. 2020. Karakteristik Tindak Tutur Direktif Tokoh Protagonis dalam Novel Cantik Itu Luka Karya Eka Kurniawan. Lingua Franca: Jurnal Bahasa, Universitas Negeri Padang.

Sosiowati, I. G. A. G. 2013. Kesantunan Bahasa Politisi dalam Talk Show di Metro TV.
Disertasi, Universitas Udaya, Denpasar.

Wijana, I. D. P. 1996. Dasar-Dasar Pragmatik. Andi Offset, Yogyakarta. 